\title{
Aurodan Tradition Value Asy-Syahadatain Cirebon Jamaah
}

\author{
A. M. Subaweh ${ }^{1}$, Sumiyad $^{2}$, T. Permadi ${ }^{3}$, Iskandarwassid $^{4}$ \\ \{1ahmadmaskur4@gmail.com, ${ }^{2}$ sumiyadi@upi.edu, ${ }^{3}$ tedipermadi@upi.edu, ${ }^{4}$ iskandarwassid@upi.edu\} \\ Universitas Pendidikan Indonesia Bandung
}

\begin{abstract}
Abstrak This study aims to examine the value of the oral traditions of the Aurodan Congregation from the Cirebon Asshahadatain Congregation. Aurodan is a tradition of prayer and dhikr together with the reading of the Cirebonlanguage nadhoman poetry which is used as a medium for the preaching of the kiyai taught at the pesantren munjul cirebon. This research is a qualitative research. Qualitative methods are used to examine objects in natural conditions, to find meaning and generalizations, where the researcher is the main instrument. This study was designed to describe, analyze, reveal, and explain the nature, value of the aurodan tradition of the Asy-Syahadatain Cirebon Session which was thoroughly researched. This study uses basic data covering the structure of the Aurodan oral tradition from the Assyahataian Congregation in Cirebon. Structure of the Aurodan oral tradition of the Assyahataian Congregation of Cirebon which includes text, context, context, participants, expressive tools, social interaction, sequence of actions. The research method used is a qualitative descriptive method with ethnographic approach. Data collection techniques are done by observation, interviews, recording and documentation, study documents. The results of this study found several values contained in the aurodan tradition both from the nadhoman poem or from other symbols contained in the tradition. We can take advantage of these values in the world of education, especially in literary learning in formal and non-formal education.
\end{abstract}

Keywords: Oral Tradition, Poetry, Values, Aurodan, Asy-Syahadatain

\section{Introduction}

Oral traditions can still be found in traditional societies or communities, although their numbers continue to decrease with the influence of modernization and globalization of culture. Oral tradition has long been used as a medium to teach the traditions of the past to the young generation. Tradition According to Sibarani [1] that the values and norms of cultural traditions and oral traditions can also be used to educate children to strengthen their identity and character in facing the future as the next generation of the nation. As a result of the lack of inheritance of oral traditions and shifts in lifestyle with modern culture, the existence of oral traditions has received less attention from the next generation. Even though there are many local values and wisdom education that are contained in the oral tradition. One of the factors is 
media inheritance that cannot be well received by the next generation. Oral tradition has a role in the process of humanization by teaching the values of character education through the messages contained in it. The process of humanization through oral literary traditions of children must be prioritized to achieve the character of children, civilized, dignified, and love to the motherland [2].

Oral traditionists would have us recognize, therefore, that texts of works identifiable as products of an oral tradition are neither mor e nor, indeed, less than written records of the words uttered by the singer or poet during a single performance. Those texts that purport to record the same poe $\mathrm{m}$ as rendered by a single performer on different occasions or by two or more performers will be bound to contain differences from one to another. For the oral epic, with which he is primarily concerned, Lord notes that, in the cases he has examined, the basic story was transmitted intact[3].

Auradan is a recitation of the poetic poetry in the ritual of wirid or collective prayer performed at the time of prayer and certain times (tawasul and marhabanan), as well as praise to the god (praises) between adzan and iqomah during prayer together mosque. The aurodan tradition studied in this study is the tradition of aurodan tawasulan, which is the tradition of praying together every Friday night as a day saved to pray for the deceased family. The AsiSyahadatain Congregational group performs prayerful rituals with loud voices and specific ways and gestures such as wind blows. They in the aurodan ritual wear white clothing consisting of a turban (headband), rida (scarf), long robes, pads, and sheaths all made of white cloth. Aurodan celebrates the cultural heritage of the Congolese Guardians in Cirebon (Jati Mountain) as the spread of Islam on Java Island. This tradition is a method of da'wah through recitation of poems in Delhi, shalawat, dhikr and prayer in Arabic as a result of the acculturation culture between Hinduism and Islam. This tradition has value that should be explored and raised to be used to inform the world of formal education especially in the study of the local charge of local literature which is the literature of Cirebon.

Value is something abstract, not concrete. Values can only be thought of, understood, and lived. Values also relate to ideals, hopes, beliefs, and things that are spiritual [4]. The value of oral tradition contains the thoughts, understanding, and appreciation contained in a tradition which is considered the most ideal relating to the beliefs of a particular community, even desirable hopes and ideals. Norm that is born of a rule that is implemented in the salapan village community both in the form of customs and laws and the law of objectivity, which is important and useful to humanity is a value [5]. Values are born from rules in the traditional community environment that obeys local customary and cultural rules [6].

That values serve as a static component in agent behaviour, whereas norms serve as a dynamic component [7]. Values and norms have different but mutually reinforcing functions in a system of community rules.Values generally consist of conscience values and giving values. Mubarok [8] explains that in general values are divided into groups, namely the values of being and values of giving. The value of conscience originates in the human heart which later becomes the beginning of the development of behavior towards other people in their social environment. Mubarok explains that the values of conscience are the values that exist in humans and then develop into behavior and the way we treat others, this value of conscience such as honesty, courage, peace, self-reliance, potential, discipline, know the limits, suitability, purity. The value of giving is able to maintain harmony between members of the community because there is an element of reciprocity between one individual with another individual, giving and receiving with equal magnitude. This value makes humans have a solid relationship in their social community, as a value that is very important for humans as social beings. Mubarok explains that giving values are values that need to be practiced and given 
which may be received as much as given. The value of giving includes loyal, trustworthy, respectful, loving, loving, affectionate, sensitive, unselfish, kind, friendly, fair and generous. This value is what makes an individual human being more beneficial to other human beings, being a virtuous person, so that value becomes something important that must be maintained in a tradition, because this value can make certain traditions useful, and we can transform values this is for the preservation of these values in human life.

The moral truths derived from society cannot supersede the moral ideal of nurturing and awakening a spiritual self into a unity of being. Thus according to the Islamic view, a moral education is one in which the physical, spiritual and psychological elements are stimulated and guided towards the good and right action [9]. The values of the pesantren tradition, especially from nadoman poetry in the aurodan tradition, can be used as norms of goodness with good habits in worship and moral messages for the people of the community.

However, the social environment of those students change since majority of the university students do not continue living with their family and start to live with their peers. Based on thistwo reality, the researcher assumes that the more university students stay at the university, the more self-transcendence values they prioritize and the less they prioritize selfenhancement values [10]. The younger generation who were educated with the values of a tradition, when they reach adulthood will be separated from the values that exist in their home environment, because they get greater influence in the new school environment. Whereas the higher level schools carry values from cultures and habits which are of course very different and affect morale beforehand.

What goes by the name of character education nowadays is, for the most part, a collection of exhortations and extrinsic inducements designed to make children work harder and do what they're told. Even when other values are also promoted -- caring or fairness, say -- the preferred method of instruction is tantamount to indoctrination. The point is to drill students in specific behaviors rather than to engage them in deep, critical reflection about certain ways of being [11]. Against the Aurodan Tradition, the Asy-Syahadatain Congregation still has not done much research on its values as an oral tradition, but for research on the Asy-Syahadatain Congregation there have been several studies from several different scientific disciplines. Thesis writing by Mahmud Sidiq, IAIN Sunan Kalijaga student, in 1987 entitled Habib Umar: Study of Personality and Struggle, The results of this study are describing the biography of Habib Umar as founder of the Asy-Syahadatain Congregation in Cirebon, but not examined the Aurodan Jamaah Asy-Asy-tradition tradition. Syahadatain so that it can be said that this research does not discuss the aurodan tradition in detail as an object of research, unlike the research that I am going to do that is examining the Aurodan tradition of the Asy-Syahadatain Jamaat, especially its value study. There is also a thesis research conducted by Luqman Hakim, a graduate student at the University of Indonesia in 2003 with the title, Work Ethics of Adherents of the Congregation: Case Study of Followers of the Asy-Syahadatain Congregation in Gebang Kulon Village, Gebang District, Cirebon Regency, the research is a qualitative study with a sociological study not from the theory of cultural studies or oral traditions. Thesis research has also been carried out on the Cirebon Asy-Syahadatain Congregation with a historical study entitled, Asy-Syadatain Cirebon Congregation from 1947 to 2001, using the Narrative Descriptive method of this study describing the history of the Cirebon Asy-Syahadatain Congregation and its development.

While the research that will be conducted by researchers is an oral tradition study of the value of the aurodan tradition of the Asy-Syahadatain Congregation which is certainly different from the previous research. formal and non-formal especially in the study of regional literature in schools or colleges. 


\section{Research Method}

The method used in this research is descriptive qualitative. The analysis was carried out with an objective approach that looked at literary works consisting of several building elements. The research design used in this study refers to an ethnographic research model that conducts observations and interviews that consider the community and cultural systems at the study site [12]. Ethnography provides guidelines for researchers in describing culture (and society) based on what exists and occurs where the culture is located (field)[13]. Ethnographic research collects data in the field and records according to what is happening, so as to produce honest and objective descriptions of culture and society. Researchers make observations with direct involvement, to collect data and facts that are closer to the object and more natural. Heriyawati added, ethnography was used to obtain data and facts based on direct observation. Because ethnography requires direct involvement (participant observer) of researchers on the object to be studied or described.

\section{Results And Discussion}

Having examined the aurodan tradition contains several values in it. we can use these values to shape the character of students by transforming into regional literary learning. The following values are found in the aurodan tradition.

a. Value of Togetherness

The togetherness value contained in the aurodan tradition is very clear. The aurodan / Tawassulan tradition is an activity of praying together, for the common interest, or praying for the wishes and hopes of one of the worshipers who hold the aurodan tradition for personal gain. In some movements and formations in prayer, symbols of togetherness can also be seen, such as praying by making a tight circle, praying by sitting and standing and chanting dhikr, prayers, blessings, and poetry nadoman advice that speaks cirebon together with one rhythm same. The value of togetherness is also seen at the end of the prayer activity which is followed by the activity of eating together with dishes collected from the congregation themselves.

b. Mutual Mutual Value

The value of mutual cooperation in the aurodan tradition is illustrated from the preparation in the tradition of the diversity of this joint dhikr, namely the pilgrims preparing everything together. Each member in this group helps each other prepare food dishes that are offered from several people to be eaten together after the aurodan / tawassulan ritual is finished.

c. Inner Value (God Blessings)

The value of inhumanity is the value of the concept of divinity that expresses the oneness of God, which strives to avoid His belief and supernatural actions with other things (shirk). In this aurodan tradition it teaches the value of inhumanity by reading the words of the Creed of monotheism as wirid which is repeated many times in the aurodan / tawassulan tradition of the Ash-Syahadatain Congregation. The value of inhumanity is also evident in some of the foundational verses sung in the aurodan tradition.

d. The value of repentance (abandoning the bad in remembering God)

Repentance is a value that teaches us to abandon acts that are considered to be in violation of religious rules and norms by remembering God. This Aurodan tradition teaches the value of repentance in its ritual structure, marked by the repeated reading of Istigfar sentences 
throughout the ritual. The Istigfar (Astaghfirullah) sentence in the teachings of Islam is a symbol of God's forgiveness (Allah).

e. Satisfaction value (not greedy for worldly pleasures)

The value of Satuh is the value of avoiding the greedy nature of worldly pleasures.

\author{
Nure Kanjeng Nabi kang bagi Kanjeng Nabi \\ Nure Kanjeng Nabi kang bagi Kanjeng Nabi \\ Yen kebagi bagen mlarat tetep sugih \\ Yen kebagi bagen mlarat tetep sugih
}

Kang aran sugih bunga susah eling Allah

Kang aran sugih bunga susah eling Allah

Serta manut parentae Rosulullah

Serta manut parentae Rosulullah

Nadoman's poem above when interpreted as, "The Light of the Prophet who divided the Prophet, if divided even though poor still rich, whose name is rich it is hard to remember Allah, and obey the command of the Prophet". This poem explains that the name of wealth is not having abundant wealth in the world, but the ultimate wealth is to remember God in joy or sorrow which results in wealth in the hereafter because he always worship whatever the conditions. So it can be said that the poem is trying to teach the concept of the value of not loving something worldly in excess, but we should still focus on worship even though the conditions are not always in happiness.

f. The value of patience (accepting all trials)

The value of patience is also embedded in the aurodan tradition in each of the long stages in this joint prayer activity which can take from one hour to two hours in its implementation. So to say this ritual requires patience in living it.

g. Charity Value

The value of giving alms or giving to others is also expressed in the aurodan tradition, that is, anyone can provide food and drinking water for worshipers who pray in this tradition. Alternately and voluntarily every member of this tarekat. The food served will be eaten together after performing the ritual, bringing social relations between members of the congregation closer together and eating afterwards.

$\mathrm{h}$. The value of exercise

The value of exercise is also found in this aurodan tradition because the activity of praying together is carried out in motion not only silent, with a circular formation sitting and then standing, everyone in this tradition moves like grass in the wind, standing and moving to the right and left as blown the wind from the right and left side while singing a prayer and poetry in Cirebon language called nadoman. So that this activity produces movements that are very healthy for the body like exercise, but do not leave the spiritual value.

The value of togetherness shown in the aurodan tradition is a reflection of the attitude of the Cirebon people who uphold common interests above personal interests. Aurodan is not just a ritual of praying together, but a religious ritual that fosters a good social life, they can meet each other, tell stories to each other, and spend time by eating together. Togetherness can be seen when the prepared food is eaten together at the place after the aurodan activity is finished. The aurodan tradition is also used to help each other, empathize, with our brothers and neighbors because this tradition is also used to help our brothers, our neighbors who have problems, who are being tested and calamity, this ritual is used to ask God (Allah) to lift the 
test and strengthen the hearts of those who are being tested to be patient and not restless. Someone who gets the exam usually invites other worshipers to do the tawasullan (aurodan) tradition to facilitate their affairs. The value of this togetherness is very pronounced where at the beginning of the aurodan activity it is usually the host who invites his congregation to come to pray together declaring prayer assistance at the beginning of the activity, when the aurodan tradition will begin.

The value of mutual cooperation shown in the Aurodan tradition is very thick, this value is taught through mutual assistance in preparing food from several worshipers when this activity is carried out in the mosque. This indicates the attitude of mutual cooperation. The attitude of mutual help and mutual cooperation is a local wisdom that we rarely encounter in increasingly modern society. Technological development makes society become individualists and leave the value of mutual cooperation. However, this tradition seems to be a medicine for the people in Cirebon, making the pilgrims become aware of the importance of the value of this mutual cooperation, because by working together we can relieve heavy tasks and problems.

\section{Conclusion}

Based on observations, interviews and analysis of aurodan text documents, it can be concluded that the aurodan tradition is a tradition that is used to pass on values which are the requirements of local wisdom to the next generation, especially for the followers of the AsySayahadatain cirebon congregation. However, when examined more deeply this value is universal and can be used for the benefit of humanity in general, especially human beings who are Muslim in carrying out life in society.

The values contained in the aurodan tradition are more about how humans view life more wisely and wisely. This Aurodan tradition teaches us through symbols and poetry nadoman poetry to navigate life with a strong work ethic, tough, not giving up, working hard, being humble, sharing, working together, making changes, praying a lot and always involving interventions the hand of God in all matters and problems of life.

The aurodan tradition is a tradition that we cannot possibly keep forever from extinction, because the development of the times may one day be lost depending on the user community. However, the values contained in it can still survive through the process of transformation or we can take it to be used as material or learning material for regional literature in formal and non-formal education.

\section{References}

[1] R. Sibarani, Kearifan lokal: Hakikat, peran, dan metode tradisi lisan. Jakarta: ATL., 2012.

[2] I. M. Suarta, "Revitalization of oral literature tradition of Balinese society based character values as deradicalism effort," Int. J. Soc. Sci. Humanit., vol. 1, no. 3, pp. 8-16, 2017, doi: 10.29332/ijssh.v1n3.48.

[3] M. Zwettler, Oral tradition of classical Arabic poetry: its character and implications. The Ohio State University Press.

[4] A. Istian, I., Hudiyono, Y., \& Rokhmansyah, "Bentuk, Fungsi, dan Nilai Tuturan dalam Upacara Adat Biduk Bebandung Suku Bulungan: Kajian Folklor,” J. Bahasa, Sastra, Seni dan Budaya, vol. 1, no. 4, pp. 265-278, 2017.

[5] L. Wahyudi, M. T. Zuhri, A. Mahfudin, K. Ramdani, and N. Ahmad, "Character Education 
Values in the Tradition of Salapan Village Community as a Form of Local Wisdom," vol. 253, no. Aes 2018, pp. 401-404, 2019, doi: 10.2991/aes-18.2019.91.

[6] K. Saddhono, N. E. Wardani, and C. Ulya, "Sociopragmatic approach on discourse structure of friday prayer's sermon in java and madura island," J. Lang. Lit., vol. 6, no. 1, pp. 26-29, 2015.

[7] R. Mercuur, V. Dignum, and C. M. Jonker, "The value of values and norms in social simulation," Jasss, vol. 22, no. 1, 2019, doi: 10.18564/jasss.3929.

[8] Z. Elmubarok, Membumikan pendidikan nilai: Mengumpulkan yang terserak, menyambung yang terputus, menyatukan yang tercerai. Bandung: Alfabeta, 2009.

[9] M. Chowdhury, "Emphasizing Morals, Values, Ethics, and Character Education in Science Education and Science Teaching.," Malaysian Online J. Educ. Sci., vol. 4, no. 2, pp. 1-16, 2016.

[10] M. F. Yigit, "Does Higher Education Change Value Perceptions?," vol. 1, no. 1, pp. 1-8, 2018.

[11] J. Holt, "How children fail," J. Read. Spec., vol. 6, no. 1, pp. 4-7, 1966, doi: $10.1080 / 19388076609556948$.

[12] Mc Millan \& Shcumacher, Reseach in education. San Fransisco: Adison Wesley Longman, Inc, 1997.

[13] Y. Heriyawati, Seni pertunjukan dan ritual. Yogyakarta: Ombak, 2016. 